VOLUME 78 PART 2 APRIL 1979 PARAAE 78 (Pt 2) 107-250 (1979) 0031-1820

|
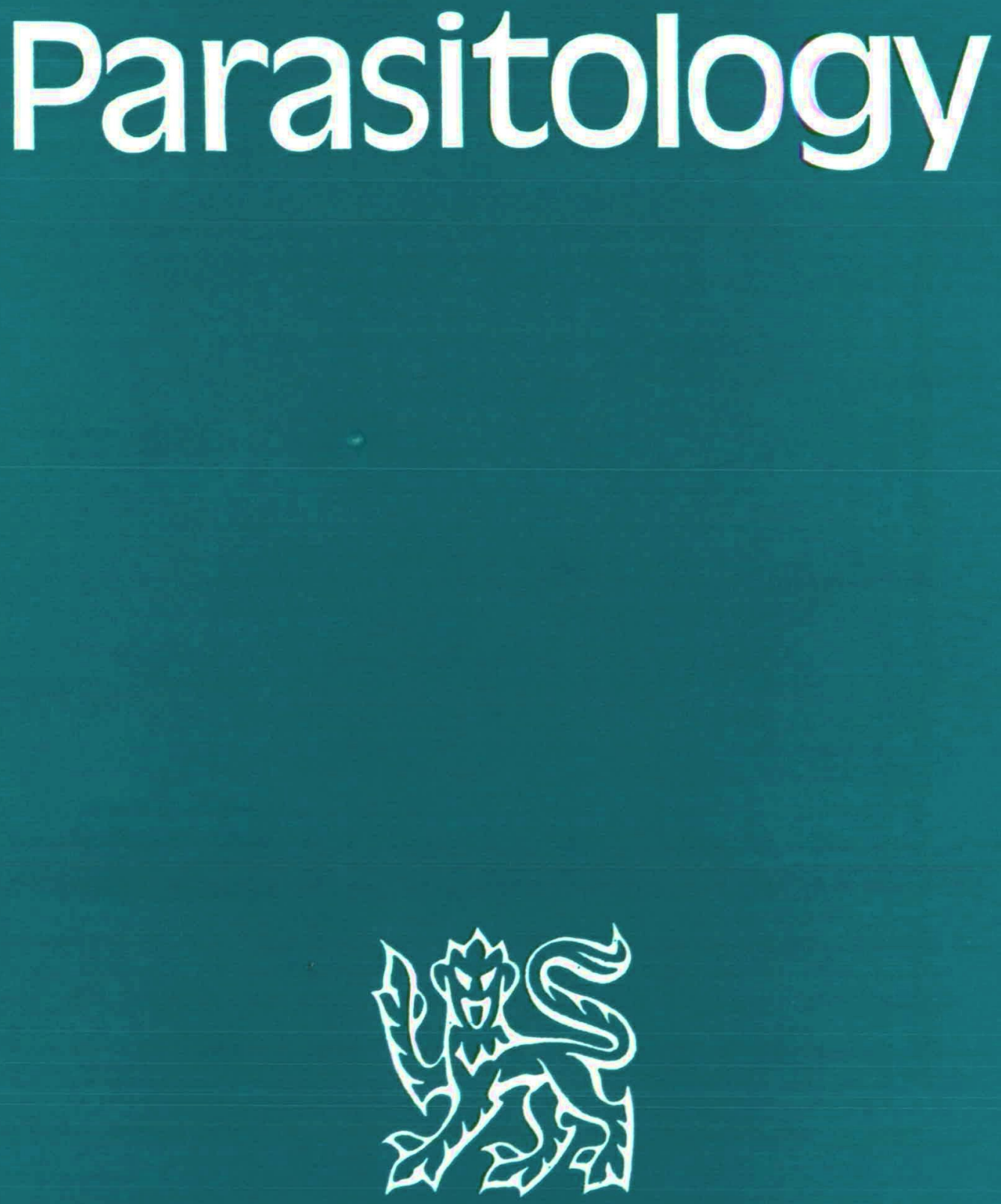


\section{PARASITOLOG Y}

(FOUNDED BY G. H. F. NUTTALL)

EDITORS

D. W. T. CROMPTON and B. A. NEWTON

The Molteno Institute, Downing Street, Cambridge, England

EDITORIAL ASSISTANT

M. ELISABETH PAINTER, Ph.D.

EDITORIAL POLIOY

Parasitology publishes original results from pure and applied studies of parasites and hostparasite relationships. In addition to papers describing the taxonomy, life-cycles and ecology of parasites, the editors will be pleased to consider reports of experimental work on biochemical, immunological and physiological aspects of parasitism and the chemotherapy of parasitic diseases. Contributors are strongly advised to prepare their typescripts in the manner set out in the Instructions to Authors included in each part of the journal. The editors assume that papers submitted to Parasitology are not being considered for publication in other journals and do not contain material which has already been published.

ADVISORY BOARD

GWENDOLEN REES, F.R.S. (Chairman)
R. ANDERSON
D. I. GIBSON
J. H. ROSE
D. R. ARTHUR
L. G. GOODWIN, F.R.S.
J. F. RYLEY
J. R. BAKER
L. P. JOYNER
G. SALT, F.R.S.
J. BARRETT
C. R. KENNEDY
S. R. SMITHERS
ELIZABETH U. CANNING
ANN M. LACKIE
K. VICKERMAN
L. H. CHAPPELL
D. L. LEE*
D. WAKELIN
S. COHEN
R. J. LINCOLN
P. F. V. WARD
R. R. A. COOMBS, F.R.S.
J. LLEW ELL YN
P. J. WHITFIELD
F. E. G. $\operatorname{COX}$
S. H. P. MADDRELL
H. H. WILLIAMS
G. A. M. CROSS
BRIDGET M. OGILVIE
R. A. WILSON
D. A. ERASMUS
M. ELAINE ROSE
C. A. WRIGHT

* Representing the British Society for Parasitology.

PARASITOLOGY is published once every two months. Each volume consists of three parts (published in February, April, June, August, October and December) plus indices.

SEOOND CLASS POSTAGE PAID AT NEW YORK, N.Y.

Information on subscriptions, back volumes, permissions and advertising is given on the inside back cover.

(C) Cambridge University Press 1979

The Pitt Building, Trumpington Street, Cambridge CB2 1RP

Bentley House, 200 Euston Road, London NW1 2DB

32 East 57th Street, New York, N.Y. 10022 


\section{PARASITOLOGY}

\section{INSTRUGTIONS TO AUTHORS}

Manuscripts must be written in English and sent to the Editors, Parasitology, The Molteno Institute, Downing Street, Cambridge CB2 3EE, U.K. The original manuscript and one copy should be submitted.

Submission of a manuscript implies that it has been approved by the named authors, that it reports their unpublished work and that it is not being considered for publication elsewhere.

1 Style. Manuscripts must be typewritten in double spacing and all pages should be numbered consecutively. Although 'short communications' in the form of preliminary notes are not accepted there is no lower limit on manuscript size, provided that sufficient experimental details are given. Authors should, as far as possible, adhere to the following format:

(a) Title-page, headed by a concise but informative full title (a running title of not more than 44 letters should also be supplied), name(s) of author(s) and address of the institute where the work was carried out. (Footnotes indicating present address may be included on the title-page.)

(b) Summary, containing brief but informative details of the contents and conclusions of the paper. It should normally constitute about 3-4\% of the extent of the paper and preferably not exceed 200 words.

(c) Introduction, stating the reasons for doing the work.

(d) Materials and Methods. Particular care must be taken to ensure that sufficient experimental details are given so that methods can be reproduced by readers.

(e) Results should be described as concisely as possible and the use of both tables and figures to present the same data is to be avoided.

(f) Discussion should not recapitulate results in detail or contain new information but should emphasize the relevance and significance of the findings reported.

(g) Acknowledgements.

(h) References. Correct references are the responsibility of the author. The Harvard System must be used for the citation of references in the text as follows: Brown \& Green (1960) or (Brown \& Green, 1960). Where there are more than two authors the first citation should include all the names and subsequent citations should be in the form Brown et al. (1960) or (Brown et al. 1960). Where several papers by the same author(s) have been published in the same year they should becited as Brown $(1960 a, b)$. Sometimes an author may wish to refer to his unpublished work or to information supplied by colleagues. In such cases the terms 'unpublished observations' and 'personal communication' may be used. Reference to papers 'in preparation' should be avoided and only cited in exceptional circumstances. Citation of papers 'in press' is acceptable. At the end of the paper references must be listed in alphabetical order of authors' names. Both the title of the paper and of the journal should be given in full according to the following style:

EVErand, L. K. \& RitchiE, L. A. (1972). Infectivity of cercariae of Schistosoma mansoni from snails on inadequate diets. Parasitology, 64, 441-4.

Roazes, W. P. (1962). The Nature of Parasitism. Now York and London: Academic Press.

HoNIGBERG, B.M. (1967). Chemistry of parasitism among some protozoa. In Chemical Zoology, vol. 1 (ed. M. Florkin, B. T. Scheer and G. W. Kidder), pp. 695-814. New York and London: Academic Press.

2 Animals and organisms. The full binomial Latin name (underlined) should be given for all experimental animals except common laboratory animals and where possible the strain and source should be stated. Authors should follow the International Rules of Nomenclature for organisms and when new names are introduced the recommendations of the Inter. national Code of Zoological Nomenclature should be followed. 
3 Solutions. Concentrations should be expressed in terms of molarity (M) not normality (N) and fractional concentrations should be given as $0.1 \mathrm{M} / \mathrm{HCl}$ not as $\mathrm{M} / 10 \mathrm{HCl}$. Concentrations given as $\%$ must be defined as $w / w, w / v$ or $v / v$. The complete composition of buffer systems should be given at the first mention. The names and addresses of manufacturers of special apparatus or materials should be stated. The EC numbers of enzymes should be given and nomenclature should follow the system published in the Report on the Commission on Enzymes of the International Union of Biochemistry.

4 Symbols for physical units. Recommended SI symbols for units should be used; for example, see the list of commonly used preferred units below. For precise definitions of SI units authors should refer to Units, Symbols and Abbreviations: $A$ Quide for Biological and Medical Editors and Authors; obtainable from the Royal Society of Medicine, 1 Wimpole Street, London W1M 8AE.

\begin{tabular}{|c|c|c|c|c|c|c|c|}
\hline \multicolumn{2}{|c|}{ Basic SI units } & \multicolumn{6}{|c|}{ Prefixes for $S I$ units } \\
\hline $\begin{array}{l}\text { Metre } \\
\text { Kilogram }\end{array}$ & $\mathbf{m}$ & $\begin{array}{c}\text { Factor } \\
10^{-1}\end{array}$ & $\begin{array}{l}\text { Prefix } \\
\text { deci }\end{array}$ & Symbol & $\begin{array}{c}\text { Factor } \\
10^{1}\end{array}$ & Prefix & Symbol \\
\hline Second & sec & $10^{-2}$ & centi & $\mathrm{c}$ & $10^{2}$ & hecto & $\mathrm{h}$ \\
\hline Ampere & A & $10^{-3}$ & milli & $\mathbf{m}$ & $10^{3}$ & kilo & $\mathbf{k}$ \\
\hline \multirow[t]{15}{*}{ Mole } & mole & $10^{-6}$ & micro & $\mu$ & $10^{6}$ & mega & $\mathbf{M}$ \\
\hline & & $10^{-9}$ & nano & n & $10^{9}$ & giga & $\mathbf{G}$ \\
\hline & & $10^{-12}$ & pico & $\mathrm{p}$ & $10^{12}$ & tera & $\mathbf{T}$ \\
\hline & & \multicolumn{2}{|c|}{ Length (metre) } & \multicolumn{2}{|c|}{ Weight $(\mathrm{kg})$} & & \\
\hline & & \multicolumn{2}{|c|}{$\mu \mathrm{m}$} & \multicolumn{2}{|l|}{$\mu \mathrm{g}$} & & \\
\hline & & \multicolumn{2}{|c|}{$\mathrm{mm}$} & \multicolumn{2}{|l|}{$\mathrm{mg}$} & & \\
\hline & & \multirow{2}{*}{\multicolumn{4}{|c|}{$\begin{array}{r}\text { cm } \\
\text { millimicr }\end{array}$}} & & \\
\hline & & & & & & & \\
\hline & & \multicolumn{2}{|c|}{ Volume (litre) } & \multirow{2}{*}{\multicolumn{2}{|c|}{ Temperature }} & & \\
\hline & & \multirow{2}{*}{\multicolumn{2}{|c|}{$\begin{array}{l}1 \mathrm{ml} \\
1 \text { litre }\end{array}$}} & & & & \\
\hline & & & & & & \\
\hline & & \multirow{2}{*}{\multicolumn{2}{|c|}{$\begin{array}{l}\text { Tot allowed } \\
\text { inch }\end{array}$}} & \multicolumn{2}{|c|}{ SI unit equivalent } & & \\
\hline & & & & \multicolumn{2}{|l|}{$2.54 \mathrm{~cm}$} & & \\
\hline & & \multicolumn{2}{|c|}{ angstrom } & \multicolumn{2}{|c|}{$10^{-10} \mathrm{~m}$ or $0.1 \mathrm{~nm}$} & & \\
\hline & & \multicolumn{2}{|c|}{ atmosphere } & \multicolumn{2}{|c|}{$\begin{array}{c}760 \times 133.1 \mathrm{~N} / \mathrm{m}^{2} \\
=101.3 \mathrm{kPa}\end{array}$} & & \\
\hline
\end{tabular}

5 Abbreviations. These should be used sparingly and should be spelled out in full on first use. The following list provides a guide to some of the commonly used abbreviations.

$\begin{array}{ll}\text { acceleration due to gravity for centrifugal conditions } & \text { g } \\ \text { compare } & \text { cf. } \\ \text { counts per minute } & \text { c.p.m. } \\ \text { curie } & \mathrm{Ci} \\ \text { degrees of freedom } & \text { D.F. } \\ \text { disintegrations per minute } & \text { d.p.m. } \\ \text { effective dose (median) } & \text { ED }_{50} \\ \text { experiment(s) (with reference number) } & \text { Exp., Exp. 2 and Exps 3-11 } \\ \text { gas-liquid chromatography } & \text { g.l.c. } \\ \text { haematoxylin and eosin } & \text { H and E } \\ \text { haemoglobin } & \text { Hb } \\ \text { immumoglobulins } & \text { IgG, otc. } \\ \text { international unit } & \text { i.u. } \\ \text { intramuscular } & \text { i.m. } \\ \text { intraperitoneal } & \text { i.p. } \\ \text { intravenous } & \text { i.v. } \\ \text { isotopes } & {\left[{ }^{32} \text { ]creatinine, [1-2H]ethanol, }\right.} \\ & \text { L-[2-14C]leucine }\end{array}$




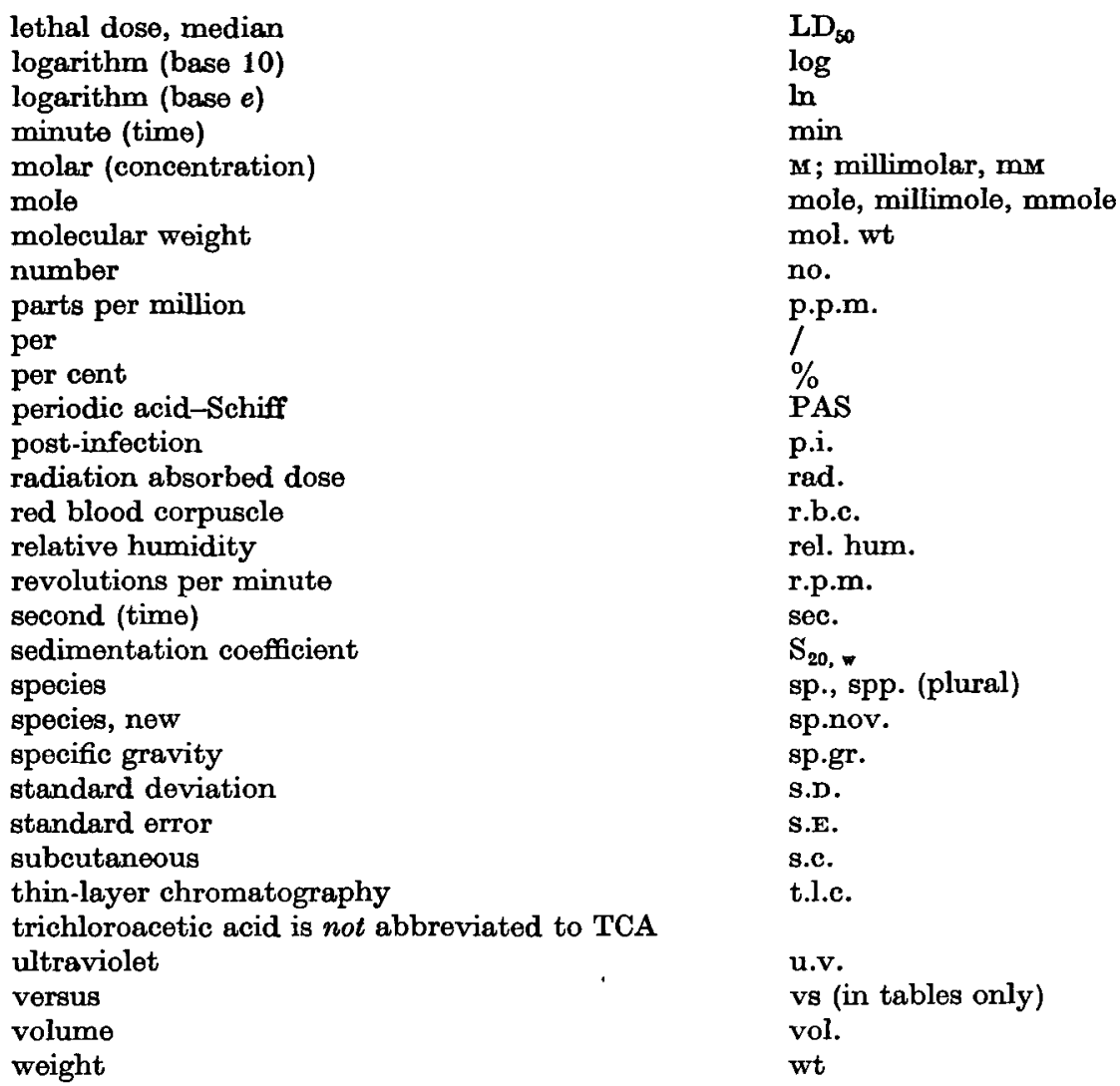

6 Statistical treatment. Where possible, data from sufficient numbers of separate experiments should be reported to permit assessment of the reproducibility and significance of the results. Where a significant difference is claimed between the means of two groups of results, the kind of test significance used should be stated. It should be made clear whether the standard deviation or standard error has been used, and the number of separate experiments should be given.

7 Powers in tables and figures. Where powers are used to avoid writing out large numbers, care must be taken to express these correctly, e.g. $2 \cdot 3$ under the heading $10^{3} k$ means that the value of $k$ is $0.0023 ; 2.3$ under the heading $10^{-3} k$ means that the value of $k$ is 2300 . Similarly, a concentration of $0.0015 \mathrm{~m}$ should be expressed as 1.5 under the heading $10^{3} \times$ conc. (M) not as $10^{-3} \times$ conc. (M). The unit may be changed by the use of prefixes, e.g. $\mathrm{m}, \mu, \mathrm{n}$ or $\mathrm{p}$, etc.

8 Illustrations. Each illustration should be supplied on a separate sheet and be labelled with the author's name and the figure or table number. The approximate position of figures and tables should be indicated in the text.

(i) Headings and legends. Each table, figure or plate should be supplied with an informative heading which together with an explanatory legend should provide enough details to make reference to the text unnecessary.

(ii) Figures. These should be drawn about twice the size of the finished block. The maximum printed size of any drawing or group of drawings is $200 \times 125 \mathrm{~mm}$. Explanatory lettering will be inserted by the printers and should be indicated in soft pencil or on a tracing-paper overlay. Excessive lettering should be avoided on the figure and should be inserted in the legend. The preferred symbols for use in figures 
are $O, \Delta, \square, O, \Delta, \square$, and for consistency, the same symbols should be used to represent the same entity throughout the paper. Figures should be referred to in the text as Fig. 1; Figs 1-3.

(iii) Plates. Photographs for plates should be mounted on card and should be approximately the same size as they are to appear in the journal, i.e. they should not exceed $200 \times 125 \mathrm{~mm}$. Lettering on plates will be inserted by the printers and should be indicated on a tracing-paper overlay. Explanations of abbreviated lettering should be given as a separate list or included in the legend. Each plate should be supplied with a scale bar with the appropriate units; magnification factors must not be given as an alternative. Mounting photographs is the responsibility of the author(s). Where several photographs make up a plate, they should be accurately mounted on card and labelled. Plates will be referred to in the text as Pl. $1 \mathrm{~A}$; Pls 1 and 3.

Plates of electrophoresis patterns should always be submitted together with line drawings. Electrophoresis conditions should be stated in the legend. Authors may be asked to contribute to the cost of plates in excess of four.

9 Proofs. Page proofs will be sent to the author by the Press. They will already have been proof-read by the Press for printer's errors but it is the responsibility of the author to ensure that the proof contains no errors. Only essential corrections should be made and authors may be charged for excessive alteration in proof.

10 Offprints. Authors will receive 50 offprints free of charge and may order additional copies from the Press.

\author{
D. W. T. OROMPTON \\ M. EIISABETH PAINTER \\ B. A. NEWTON
}

